\title{
Accounting for Environmental Liabilities - Case of Albania
}

\section{Dr. Albana Jupe}

Lecturer at Finance-Accounting Department, Faculty of Agribussines and Economy, Agricultural University of Tirana, Kamez, Tirana

Email: albanajupe@gmail.com

MSc. CA. Lirola Këri

International Accounting Standard Supervisor-National Accounting Council of Albania

Blv. "Dëshmorët e 4 Shkurtit" Nr. 6, Tiranë

Email: lirolakeri@gmail.com

MSc. Rajmonda Biracaj

Lecturer at Finance-Accounting Department, Faculty of Agribussines and Economy, Agricultural University of Tirana, Kamez, Tirana

Email: raimondabiraci@yahoo.com

MSc. Alda Taka

Lecturer at Finance-Accounting Department, Faculty of Agribussines and Economy, Agricultural University of Tirana, Kamez, Tirana

Email: aldataka@gmail.com

Doi:10.5901/ajis.2014.v3n3p283

\section{Abstract}

Environmental issues are now in focus of corporate performance requiring not only the respecting of rules on environment but as well reflecting the cost of environmental damages during the financial reporting. The current financial accounting practices do not cover all the environmental cost caused from the companies. As result a new field of accounting emerged, environmental accounting that takes into consideration the concern on environment and natural resources, stating the values of the positive and negative public effects and externalities and incorporating them in the traditional accounting (Balance Sheet and Income Statement). The role of accounting on monitoring the environmental degradation caused from firms operating in Albania will be the focus of this study. The accounting legislation and regulation of Albanian firms will be examined stating the approach towards environmental damages. Accounting practices of three companies with negative impact on the environment will be analyzed. The study finds that the accounting practices and regulation in Albania do not have the proper structure on reporting the environmental issues.

\section{Introduction}

Environmental degradation is currently a major issue being addressed in governmental policies and strategies which are recently designated in Albania. Albania has signed Kyoto protocol on climate change by creating the opportunity to participate in the market emissions. Monitoring the physical and chemical indicators shows a continuous increase of this contamination, facts that are published in many studies conducted in Albania on environmental sustainability. In many of these studies has been recommended continuous monitoring and taking measures to protect the environment. The main activities that cause pollution in Albania are considered the development of industry and agriculture sector. The studies conducted on environmental degradation in Albania lack real figures regarding the costs on environmental hazards.

Meanwhile in the framework of the Kyoto's protocol signing, the Board of the International Accounting Standards has established rules regarding carbon market and specifically giving accountancy treatment spaces as active immaterial (IAS 38) and the case of IAS 20 (the allowances are treated grants).

In the last decades there has been an increased pressure from the government especially in the developed countries where rules in power demands from the firms the reporting of environmental damages. Measuring this impact is a very demanding issue, urged by the pace at which ecosystems are destroyed (MEA, 2005) and incidents with 
environmental consequences occur: for example, in the sole 2011, the nuclear disaster of Fukushima following the earthquake in Japan, four oil spills a $200 \%$ increase in the number of forest fires in Italy have been registered at different scales (Defrancesco, 2012). Among the initiative undertaken in framework of environmental costs identification and disclosure a new document has been designated entitled Towards Sustainability as part of its Fifth Action Programme, which suggests that the accounting profession take a role in implementing costing systems that internalize environmental costs previously ignored. Specifically, EU called for a 'redefinition of accounting concepts, rules, conventions and methodology so as to ensure that the consumption and use of environmental resources are accounted for as part of the full cost of production and reflected in market prices' (European Commission 1992, cited in Deegan 2006).

Many companies have embraced the corporate social responsibility stressing their willing to serve the community. In order to optimize corporate environmental and economic performance and achieve sustainable business challenges the responsibility against society and environment should be fulfilled. In case of failure and disability to meet the rules the companies would not have the opportunity to recover the license affecting in the main objective of the firm to increase the value in unlimited time. For this reason there is an increase of attention towards the inclusion of environmental impacts in conventional accounting. In order to monitor the environmental damages, to monitor the cost and control the savings is necessary that accounting disciplines to be involved.

Recently the research that has been carried out has assessed the contribution of accounting in environment management as well as has identified the gaps regarding reporting firm's externalities in the existing conventional accounting. (e.g. Bartolomeo et al. 2000; Bennett, Bouma \& Wolters 2002; Bennett \& James 2000; Bennett,Rikhardsson \& Schaltegger 2003; Deegan 2003; IFAC 2005).

Several limitations of conventional management accounting systems and practices on collecting and evaluating environment-related data lead to the emerge of new discipline called environmental accounting.

Environmental accounting takes into consideration the concern on environment and natural resources, stating the values of the positive and negative public effects and externalities and incorporating them in the traditional accounting (Balance Sheet and Income Statement). "Environmental Accounting is the task of measuring and monitoring your impact on the environment on overall level, including waste, omission, spill, leakage, consumption, noise and all other environmental impact factors. This must be done in auditable, traceable, proven manner to explain and justify your performance to internal and external sources, just like you would do for financial operations or production operations" (Okoye , 2005 et al)

The aim of this paper is to analyze the financial reporting in Albania in relation to the disclosure of externalities, especially the current accounting practices that a company with evident environmental damages uses to inform the decision makers.

The structure of this paper will be as follows: findings and conclusions reached by the authors who conducted studies in relation to financial reporting in connection with environmental degradation will be brought in the second chapter, the review of literature. Methodology and research question will be described in the third chapter. In the fourth chapter results and discussions based on analysis of accounting procedure followed from three companies are concluded.

\section{Methodology}

The main problem that this study addresses is to what extent the firms that operate in our country identify the environmental costs and includes them in financial reporting. For this reason two main questions are posed in this study:

1. Do the accounting regulations provide the conceptual and technical background necessary for the reporting of environmental liabilities in Albania?

2. How does the legal requirement on respecting environment impose the firms to inform on environmental damages?

For answering these questions we examined the national guidelines on financial practices, environmental laws, the existing international accounting standards and companies practices on financial and environmental reporting. Reports and information regarding the performance of three companies provided by various sources were analyzed in order to understand the company's approach towards environmental issues.

\section{Literature Review}

In global level, for economic policies developed after 30s there was a need to account primarily for economic financial aggregates like investment, production, demand and employment. When scarcity of natural resources and environment 
degradation/depletion became at least equally important, in the second half of $20^{\text {th }}$ century, methods of accounting needed to be changed to reflect the new reality (Merlo, et al 2001). Environmental accounting was first developed in the $60 \mathrm{~s}-70 \mathrm{~s}$ at a national level in order to answer growing worry about the state of the environment and related natural resources, calculating the so-called Net Economic. Furthermore guidelines to adjust national accounts have therefore been provided (United Nations, 1968), Bruntland Committee (1987) and the Rio Summit (1992).

Among the initiatives taken in relation to identification and disclosure of environmental cost is the document entitled Towards Sustainability as part of its Fifth Action Programme, which suggests that the accounting profession take a role in implementing costing systems that internalize environmental costs previously ignored. Specifically, EU called for a 'redefinition of accounting concepts, rules, conventions and methodology so as to ensure that the consumption and use of environmental resources are accounted for as part of the full cost of production and reflected in market prices' (IFAC 2005).

Environmental accounting applied to a corporation includes management accounting (estimating costs of eliminating pollution on income but also as a result of efficient use of energy, water) and financial accounting (evaluation and reporting of environmental liabilities of the organization).

Environmental accounting reporting derives from conventional financial accounting and tries to integrate, step-bystep, environmental values within the accounting system. The crucial problem is how to consider the various items of the balance sheet and income statement which do not have a market price: such factors as pollution, landscape quality, biodiversity and the state of the environment, as characterized by the depletion/degradation of natural resources (Merlo, 1992). These environmental values, or impacts, are far from being well defined, let alone quantified. One reason is the difficulty of determining positive or negative impact.

In accounting, the cost is 'a resource sacrificed or forgone to achieve a specific objective... usually measured as the monetary amount that must be paid to acquire goods or services' (Horngren, Datar \& Foster 2003, p. 30). Atkinson, Kaplan and Young define environmental costs as follows:

Environmental costs fall into two categories: explicit and implicit. Explicit costs include the direct costs of modifying technology and processes, costs of cleanup and disposal, costs of permits to operate a facility, fines levied by government agencies, and litigation fees. Implicit costs are often more closely tied to the infrastructure required to monitor environmental issues. These costs are usually administration and legal counsel, employee education and awareness, and the loss of goodwill if environmental disasters occur (2004, p. 298).

Financial reporting in Albania respects the international accounting standards/national accounting standards starting from January 2008. During the implementation different issues has been faced in particular related to fiscal legislation, cultural inheritance as well the level of economic development. Apart from these difficulties the convergence of national accounting towards the international accounting is the main approach of development of accounting rules in Albania.

Even though different scholars have criticized the approach on international standards towards the environmental behavior, many standards treats directly or indirectly the environmental issues. The main aim of the accounting is to provide information to users so that they can make sound judgment/decisions. The concern of the society remains that what the law and conventions of accounting requires for disclose is insufficient given the impact of these companies in the environment where it operates (Okaye \& Ubaka 2005).

Different views are raises on the importance of international accounting standards towards the coverage of issues on environmental liabilities.

Negash examines the international accounting standards issues from IFAC, and shows the orientation towards environmental cost disclosure (Negash, 2009). So he explains, for example IFRS 6 (implementation January 2009) that directly deals with extractive industries and IFRIC 5 provides the guidance for decommissioning, rehabilitation and restoration of environment related expenditure. IFRIC 3 (still under discussion) and IAS 38 (intangibles) deal with government allocated emission rights, trades in these rights and the impairment of the emission allowances. Furthermore, it is important to note that a number of other standards provide an indirect support for the recognition, measurement and disclosure of environmental assets and liabilities. IAS 37 (provisions for contingent liabilities and assets) can be linked to environmental liabilities. IFRS 3, IAS 27, IAS 28, IAS 31, IAS 24 and IFRS 8 as well deal with environmental issues.

In our study we will be limited only in environmental liabilities accounting practices. The regulation both on accounting rules and environmental legislation in power in Albania, will guide us in in our analysis.

Accounting treatment for environmental liabilities in accordance with IAS 37 defines the following criteria on provision. "Paragraph 3 of IAS 37 defines provisions as "liabilities of uncertain timing or amount"; and contingent liability is defined as "a liability that arises from past events, and its existence will be confirmed only by the occurrence and nonoccurrence of one or more of uncertain future events that are not wholly within the control of the entity." Paragraph 14 
of IAS 37 requires that provision should be recognized when (a) an entity has a present obligation (legal or constructive) as a result of a past event; (b) it is probable that an outflow of resources embodying economic benefits will be required to settle the obligations; and (c) a reliable estimate can be made of the amount of the obligation. Paragraph 17 further defines an "obligating event" as a past event that leads to present obligation. It states that for an event to be an "obligating event", it is necessary that the entity has no realistic alternative to settling the obligation created by the event. Finally, paragraph 27 of IAS 37 deals with the disclosure conditions for contingent liabilities. If the liability is not expected to lead to an outflow of resources and where an entity is jointly and severally liable for an obligation, that part of the obligation that is expected to be met by other parties is treated as contingent liability".

\section{Results and Discussions}

In this paper the environmental reporting is examined judging based on the actual legislation on environment and the existing accounting rules and procedures. To judge on what extend the externalities are enclosed during the reporting, three companies with a considerable negative impact on the environment has been surveyed on the compliance of legal requirements and final reporting. All the companies that operate in Albania to receive the license on project application have to fulfill the law on valuation of environmental damages, Law No.10440, date 7.7.2011 "Assessment of impact in environment". The results of our paper are base mainly in the analysis made in the financial reports of important companies in three different areas, in manufacturing the cement, producing the oil and in construction. We considered the figures related to environmental liabilities and the approach that companies had in compensating the cost incurred from these negatives impacts. All the companies considered in our study have evident unpleasant effects on the area were they operate.

Analyzing the annual reports of the selected companies in our study showed up that the companies does the reporting based on traditional issues concerning the accounting policies on empower. Balance sheets, profit and loss account, cash flow statement, notes to account are well detailed respecting the rules. Also, the companies provides reports identifying issues such as environmental defense, health and safety at works, employee development and training, gifts and donations. The companies during the running of the project has to respect the approved report where are specified the impact on the environment identifying the quantity of pollutants in water, air and erosion of the surfaces around the activities development. The investment on monitoring and reducing the effects are clearly defined in the reports of companies' valuation of environment. On the other hand the annual reporting does not report these cost of investments and in particularly what effects on environment will diminished these occurred cost.

The companies report on their willing to apply the corporate social responsibility considering it as part of the company's philosophy, meaning the respect toward the human values and interest toward the environment. Policies on employment on the region, investment on infrastructure and afforestation of the areas where they operate reveal the concern of these companies toward the society. Coming back to the point of our study, no monetary values are reported or notes where to be expressed the role on environment of these policies.

As in concern the environmental provisions are taken, in the reporting of the companies that we surveyed, the provision are recognized only when the liability is raised. It is difficult that provisions to be disclosed due to the facts that the time and values are not able to be estimated. On the other hand the expenses on provisions are not recognized for fiscal regulations, considering them not appropriate to be disclosed from the management.

For this reason during the financial reporting is needed to prepare separate annexes of environmental assets and liabilities where environmental costs are identified and valuated.

\section{Conclusions}

The results of this paper provide consideration of currently existing information status and the development demand on environmental accounting in Albania. Concerning the state of environmental account in Albania it is evident that both accounting regulations in power and companies itself do not engage any particularly on environmental accounting. If any recording is done it is merely on environmental provisions applied under the international standards, IAS 37 in respect to legislation, on the other hand the reporting from companies does not comprises any obligatory report on environmental damages. In global level the impact of environmental issues has become urgent and solutions are required involving the traditional/conventional financial accounting. Therefore the financial reporting is required to disclose all the cost caused from the management decisions. This is finalized in applying environmental cost accounting system which allows us to collect, analyze record and report to our business environment.

Financial reports compilation requires that all cost occurred on pollution reduce or on prevention of further 
environmental damages to be included. This demands the interpretation of the costs as capitalized cost or expense as well the impact firm profitability. Furthermore on this framework environmental provisions have to be defined in order to specify when have to be included and to define the proper value. Nowadays in many development countries are established the practices that include the environmental costs in financial reporting stated and require from the rules and standards in power of this countries.

In this paper we found out that financial reporting does not have compliance with environmental legislation. Enterprises are required to report on environmental damages and take the necessary measures, but there is no approach towards methodology on damages valuation.

\section{References}

Atkinson, A. A., R. D. Banker, R. S. Kaplan and S. M. Young. 2001. Management Accounting 3rd edition. Upper Saddle River: NJ: Prentice Hall.

Bartolomeo, M., Bennett, M., Bouma, J.J., Heydkamp, P., James, P. and Wolters, T. (2000), "Environmental Management Accounting in Europe: Current Practice and Future Potential", the European Accounting Review, Vol. 9 No. 1, pp. 31-52.

Bennett, M., Bouma, J.J. and Wolters, T. (Eds.) (2002), Environmental Management Accounting: Informational and Institutional Developments, Kluwer Academic Publishers, Dordrecht.

Bennett, M. and James, P. (Eds.) (2000), The Green Bottom Line: Environmental Accounting for Management: Current Practice and Future Trends, 2nd edn, Greenleaf Publishing Limited, Sheffield.

Deegan, C. (2003), Environmental Management Accounting: An Introduction and Case Studies for Australia, Institute of Chartered Accountants in Australia, Melbourne.

Deegan, C. and Blomquist, C. (2006), "Stakeholder Influence on Corporate Reporting: An Exploration of the Interaction between WWFAustralia and the Australian Minerals 34 Industry", Accounting, Organizations and Society, Vol. 31 pp. 343-72.

Defranco, E. Gatto, P. Rosato, P. Bozzolan, I.(2012) The Valuation of Environmental Damage Compensation: An Integrated Framework, Retrieved from the conference web http://www.siev.org/doc/n_9_-_2012.pdf.

Horngren, CT, Datar, SM \& Foster, G 2003, Cost Accounting: A Managerial Emphasis, 11 th edn, Prentice Hall, New Jersey.

IFAC 2005, International Guidance Document: Environmental Management Accounting, International Federation of Accountants, New York.

IFAC (2005), International Guidance Document: Environmental Management Accounting, International Federation of Accountants, New York.

Law No.10440, date 7.7.2011 "Assessment of impact in environment" http://www.moe.gov.al/upload/legjislacioni/akte\%20ligjore /Ligj\%20Nr\%2010440,\%20date\%207.7.2011\%20VNM.pdf

Merlo, M. Boschetti, A. Environmental accounting in agriculture and forestry: a stepwise approach. Retrieved from the web: http://revistas.inia.es/index.php/fs

Negash, Minga, IFRS and Environmental Accounting (December 1, 2009). Available at SSRN: http://ssrn.com/abstract=1516837

Okaye, Emmalk. Ubaka, C.E. Towards a model for environment Cost Accounting: A review for the Niferian Corporate Profile (2005). Oko Journal of Bussiness Studies, Vo.4, No, 2, p.49, 2005. Available at SSRN: http://ssrn.com/abstract=1804197

U.S EPA (1995b:9). An Introduction to Environmental Accounting as a Business Management Tool: Key Concepts and Terms, Office of Pollution Prevention and Toxics, June. Retrieved Environmental Protection Agency website http://www.epa.gov/opptintr/acctg Iresources.htm 